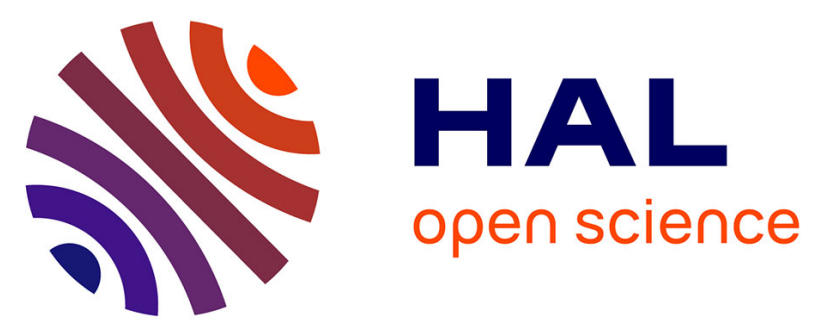

\title{
New constraints on the Upper Permian and Lower Triassic geomagnetic polarity timescale from the Abadeh section (central Iran)
}

Yves Gallet, Leopold Krystyn, Jean Besse, Luc-Emmanuel Ricou, Abdolah Saidi

\section{To cite this version:}

Yves Gallet, Leopold Krystyn, Jean Besse, Luc-Emmanuel Ricou, Abdolah Saidi. New constraints on the Upper Permian and Lower Triassic geomagnetic polarity timescale from the Abadeh section (central Iran). Journal of Geophysical Research, 2000, 105, pp.2805-2815. 10.1029/1999JB900218 . insu-01863484

\section{HAL Id: insu-01863484 https://hal-insu.archives-ouvertes.fr/insu-01863484}

Submitted on 28 Aug 2018

HAL is a multi-disciplinary open access archive for the deposit and dissemination of scientific research documents, whether they are published or not. The documents may come from teaching and research institutions in France or abroad, or from public or private research centers.
L'archive ouverte pluridisciplinaire HAL, est destinée au dépôt et à la diffusion de documents scientifiques de niveau recherche, publiés ou non, émanant des établissements d'enseignement et de recherche français ou étrangers, des laboratoires publics ou privés. 


\title{
New constraints on the Upper Permian and Lower Triassic geom agnetic polarity timescale from the Abadeh section (central Iran)
}

\author{
Yves Gallet, ${ }^{1}$ Leopold Krystyn, ${ }^{2}$ Jean Besse, ${ }^{1}$ Abdolah Saidi, ${ }^{3}$ \\ and Luc-Emmanuel Ricou ${ }^{1}$
}

\begin{abstract}
We present the magnetostratigraphy of the Abadeh section (central Iran). Thermal demagnetization shows two magnetic components: one at low unblocking temperatures, which corresponds to a present day-field direction, and another at high temperatures. This second component, which contains both polarities, is interpreted as a primary magnetization acquired during sediment deposition at a paleolatitude of about $7.7^{\circ} \mathrm{S}$. A sequence of 14 magnetic polarity zones is obtained in the intervals during the Upper Dzhulfian-Lower Changhsingian (Upper Permian) and during the Griesbachian (Lower Triassic). Combining data from south China, Canada, Pakistan, and Iran, we propose a composite (but still uncomplete) Upper Permian and Lower Triassic geomagnetic polarity timescale.
\end{abstract}

\section{Introduction}

The construction of a reliable geomagnetic polarity timescale (GPTS) during the Upper Permian and the Lower Triassic is of particular interest in order to correlate the successive events of the Permo-Triassic mass extinction, often considered as the most severe over the entire Phanerozoic [e.g., Sepkoski, 1990; Erwin, 1994]. Magnetostratigraphic studies of biostratigraphically well-dated marine sections from South China and Pakistan presently document the chronology of the geomagnetic reversals during the Upper Permian [Heller et al, 1988, 1995; Steiner et al, 1989; Haag and Heller, 1991]. More than 10 magnetic polarity intervals follow the Kiaman superchron, and the end of Kiaman would occur during the Wordian [Heller et al. 1988, 1995; Steiner et al. 1989; Haag and Heller, 1991] (see also Théveniaut et al. [1994], Embleton et al. [1996], and Gialanella et al. [1997] for continental sediments).

However, several problems still plague the construction of the Upper Permian GPTS. The Chinese sections display rather different magnetic polarity patterns and cannot be easily correlated with each other [Heller et al, 1995]. The correlations between the Nammal Gorge section from Pakistan studied by Haag and Heller [1991] and the Chinese sections are also problematic: Heller et al [1995] suggested a correlation between the Dzhulfian-Dorashamian age Chhidru formation from Nammal Gorge and the Changhsing formation from China, but it is now widely considered from biostratigraphic data that the Upper Changhsing time period is not present in Pakistan [e.g., Iranian-Japanese Research Group (IJRG), 1981; Shen et al., 1984; Sweet , 1992; Wardlaw and Pogue, 1995; Baud et al., 1996]. We felt that additional results were required to better

\footnotetext{
'Laboratoire de Paléomagnétisme et Géodynamique, UMR CNRS 7577, Institut de Physique du Globe de Paris.

${ }^{2}$ Institute for Paleontology, Vienna, Austria

${ }^{3}$ Geological Survey of Iran, Tehran.

Copyright 2000 by the American Geophysical Union.
}

Paper number 1999JB900218.

0148-0227/00/1999JB900218\$09.00 constrain the Upper Permian-Lower Triassic part of the GPTS, and thus we present a magnetostratigraphic survey of the Abadeh section (central Iran) for which numerous faunal data are available [Taraz, 1969, 1971; Kozur, 1975; Kozur et al, 1975; IJRG, 1981].

\section{The Abadeh Section}

The so-called Abadeh section (latitude $30^{\circ} 54^{\prime} \mathrm{N}$ and longitude $53^{\circ} 13^{\prime} \mathrm{E}$; Figure 1) is located in the province of Fars, about $260 \mathrm{~km}$ south of Esfahan and $60 \mathrm{~km}$ southeast of the city of Abadeh. The sequence crops out in the Hambast Range at an altitude of $\sim 2000 \mathrm{~m}$. The Uppermost Permian consists of the Hambast Formation, which has a thickness of $34 \mathrm{~m}$ in our section (Figure 2). The lower part of the Hambast Formation comprises a 17-m-thick alternating sequence of tens of centimeter thick greyish to black limestone beds and shales (unit 6 [IJRG, 1981]), while the upper part consists of reddish nodular and thin bedded limestones of ammonitico rosso type (unit 7 [IJRG, 1981]). After a distinct lithologic change, sedimentation resumed during the Lower Triassic first with a short shaly interval (30 cm of so-called Transition beds) followed by the thin bedded "en plaquettes" pale greyish limestones and shales of the Elikah Formation. This latter formation is very thick (several hundred meters) and forms cliffs in the landscape. The thin interval of stromatolites (algal biolithites) at the base of the Elikah Formation is interpreted as regressive shallow water deposits by IJRG [1981]. The studied section is monoclinal, dipping $40^{\circ}$ to $60^{\circ}$ toward the westsouthwest.

In the Tethys area, serious stratigraphic problems result from the different and competing Upper Permian chronostratigraphic scales established in China and Iran (Transcaucasia). The ammonoid faunas are unfortunately significantly different and cannot be unequivocally correlated [e.g., Zhao et al., 1978; Ruzhencev and Sarycheva, 1965] (see Tozer [1994] for a discussion). As a consequence, we consider the correlations based on conodonts far more reliable, and we use the zonation suggested by Kozur [1990, 1995] for the Permian and the one recently proposed by Orchard and Krystyn [1998] for the 


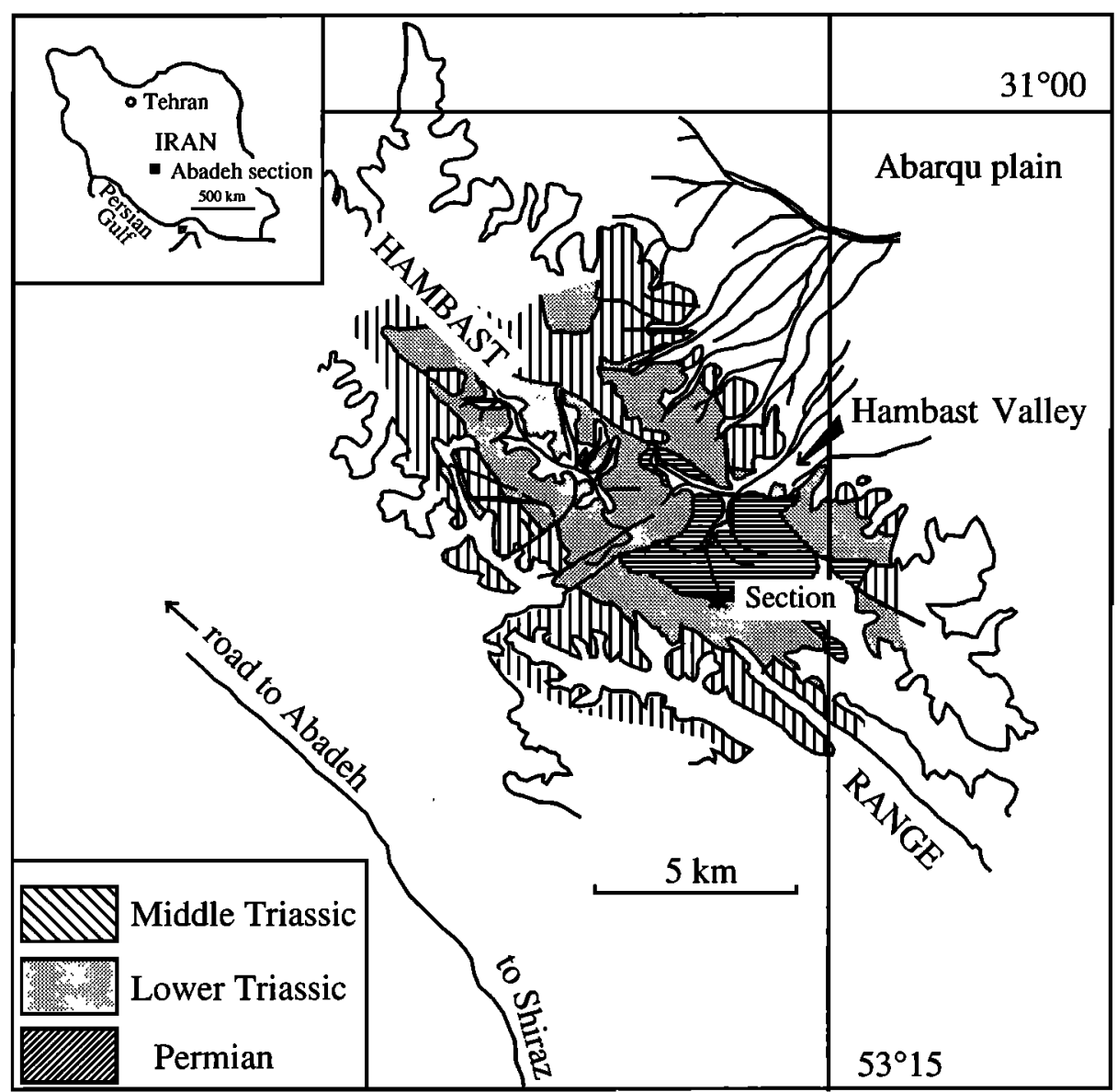

Figure 1. Locality map and simplified geological map of the Abadeh area after Taraz [1974] and the IJRG [1981]. The studied outcrop corresponds to the section C of IJRG [1981].

Triassic (Figures $3 a$ and $3 b$ ). The location of the Permo-Triassic boundary that we consider for the Abadeh section follows Tozer's [1967] definition and accords with the so-called "eventostratigraphic boundary" of Meishan [Wang, 1995] between beds 24 and 25 (in the sense of Yin et al. [1996a,b]). It reflects the major faunal turnover from Permian to Triassic neogondolellid conodonts and allows well-constrained biostratigraphic correlations between many Chinese sections [Yin et al. 1996a,b], as well as between China, Iran (Abadeh), and Canada.

The biostratigraphy of the Abadeh section was first described by Taraz [1969, 1971, 1974], and the conodonts were subsequently examined by Kozur [1975] and Kozur et al. [1975]. The most recent and most comprehensive study has been carried out by a joint Iranian-Japanese research group in 1981 . We have rechecked the Permian part of the section. The main reason for that was the correlation by IJRG [1981] of the Neogondolella orientalis conodont zone (otherwise Dzhulfian) with the Dorashamian Shevyrevites and ShevyrevitesParatirolites zones, although the Dzhulfian guide ammonite Araxoceras latum was found in the top of the Orientalis zone (Figures 2 and $3 \mathrm{~b}$ ). The detailed lithologic description of the section provided by $I J R G$ [1981] allowed us to integrate easily our new samples into the previous conodont data framework. Altogether, these data form the basis for the adopted conodont zonation of the section (Figure 2).

All samples from unit 7 of the Permian Hambast Formation are rich in diagnostic platform conodonts. The magnetostratigraphic sampling starts right above the last appearance datum (LAD) of Neogondolella leveni and of neogondolellids close to $N$. guangyuanensis (in the sense of $\mathrm{Mei}$ et al. [1994]; see also Kozur [1995]). The Upper Dzhulfian is documented within the first $7 \mathrm{~m}$ by the occurrence of both $N$. transcaucasica and $N$. orientalis. A certain differentiation of this interval is only indicated by the greater abundance of $N$. transcaucasica in the lower part. The first appearance datum (FAD) of $N$. subcarinata is above $7 \mathrm{~m}$, the conodont zonal guide of the Dorashamian, which occurs up to the top of the Hambast Formation. The Upper Changhsingian (equivalent to the Changxingensis zone) is clearly missing in Abadeh and lies within a submarine hiatus at the Permo-Triassic boundary in this region. In the Shahreza section located about $100 \mathrm{~km}$ north of the Abadeh section [Besse et al, 1998], we only found above the Paratirolites beds a $30-\mathrm{cm}$-thin nodular limestone level with Upper Changhsingian conodonts (N.postwangi, N.cf.changxingensis), similar to that of the Dorashamian type region in Transcaucasia [Kotlyar et al, 1984]. All over Iran (and Transcaucasia), the topmost Permian (i.e., Upper Changhsingian) strata are therefore very thin, either condensed or removed by lowermost Triassic submarine erosion. The paraconformity at the Permo-Triassic boundary in Abadeh claimed by Taraz [1974] and also by the Iranian-Japanese Research Group [1981] is thus a fact though it has later been rejected by Kozur [1989] and by Sweet [1992].

The marked lithologic change from the Hambast Formation to the Transition beds also records a drastic change in conodont 

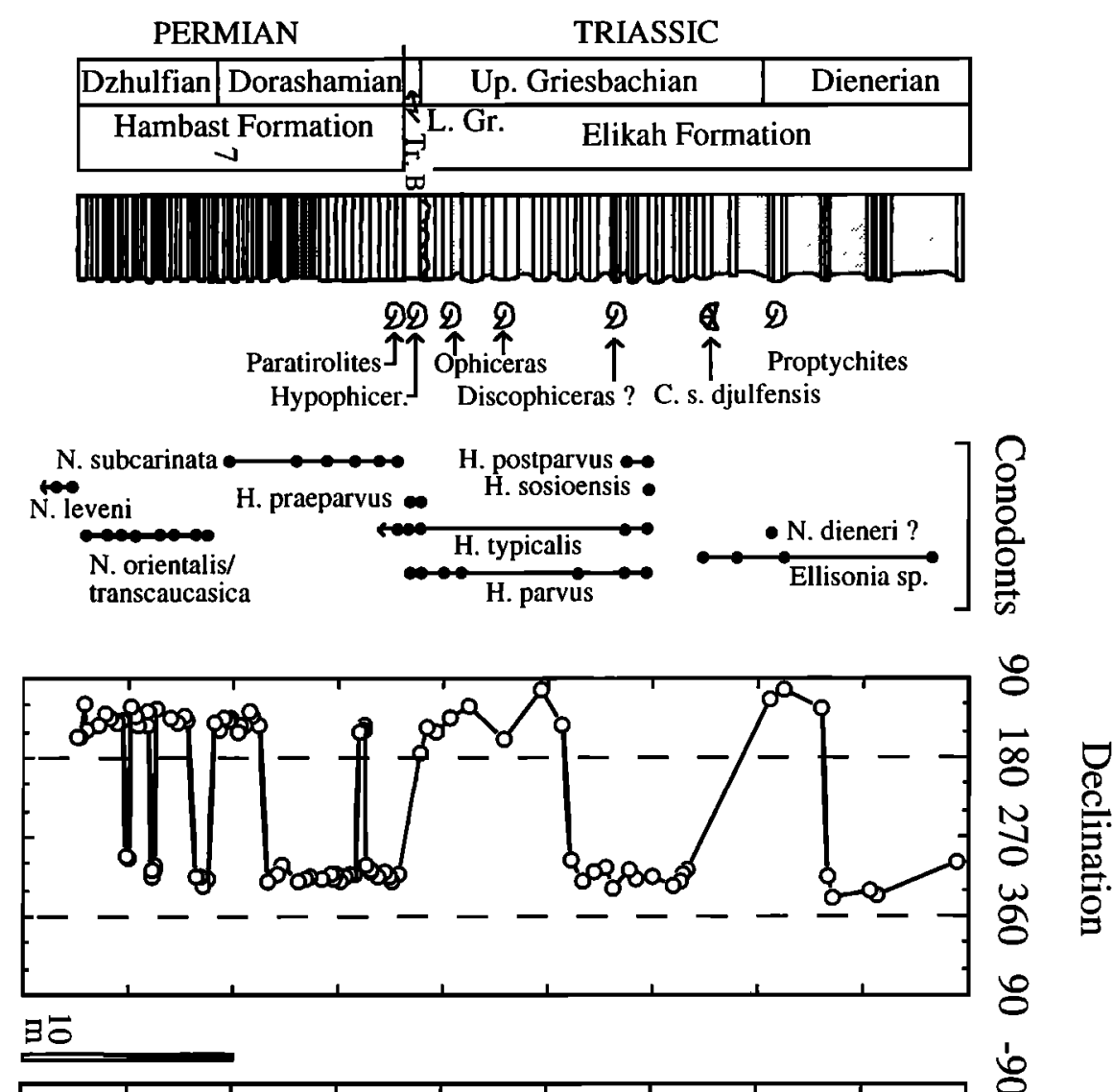

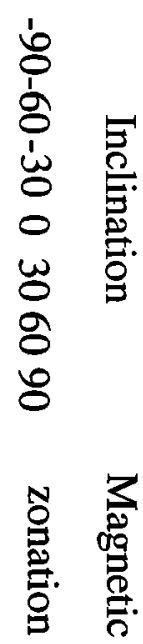

Figure 2. Lithostratigraphy, biostratigraphy, and magnetostratigraphy of the Abadeh section.

faunal composition. The pelagic genus Neogondolella is absent and is replaced by a Hindeodus-dominated and specimen-poor association. No conodonts have been extracted from the basal $20 \mathrm{~cm}$ of the Transition beds. However, a 3-cm-thin limestone layer within the upper $10 \mathrm{~cm}$ contain $H$. parvus, $H$ praeparvus, and $H$. typicalis. This fauna is not explicitly timediagnostic, but with regard to the occurrence of Hypophiceras sp. (a specimen with well-developed external suture) it is indicative of a Lower Griesbachian age (Latilobatum or Concavum? to Boreale zone). Based on the ammonite Hypophiceras, a tentative correlation is adopted with the basal shales (or Transitional beds) of the Yinkeng Formation from the Meishan section [Yin et al, 1996a]. The basal Triassic continues with Claraia and rare ophiceratid ammonite-bearing platy limestones from the Elikah Formation which contain a meager Hindeodus fauna (maximum of 20 specimens per sample). The following species have been encountered: $H$. praeparvus $(0-0.5 \mathrm{~m}$ in the Triassic part), $H$. typicalis $(0-10 \mathrm{~m}), H$. parvus $(0-11 \mathrm{~m}), H$. postparvus $(10-11 \mathrm{~m})$, and $H$. sosioensis (at $11 \mathrm{~m}$ ). A single broken and corroded fragment of a neogondolellid ( $N$. cf. subcarinata) has also been found at $0.5 \mathrm{~m}$. One more important date is the FAD of $I$ isarcica, $\sim 1 \mathrm{~m}$ above the Transition beds and directly above the last algal biolithite $[I J R G, 1981]$. The mentioned species demonstrate the presence of all Griesbachian Hindeodus/Isarcica zones in our section and provide some ground for the location of the Griesbachian/Dienerian boundary. In many Tethyan sequences (e.g., Salt Range, Kashmir, Himalayas, China) the latter is commonly placed at the FAD of Neospathodus kummeli above a Hindeodus-free interval called the Carinata zone by Sweet [1970]. This interval is thought to 
a)

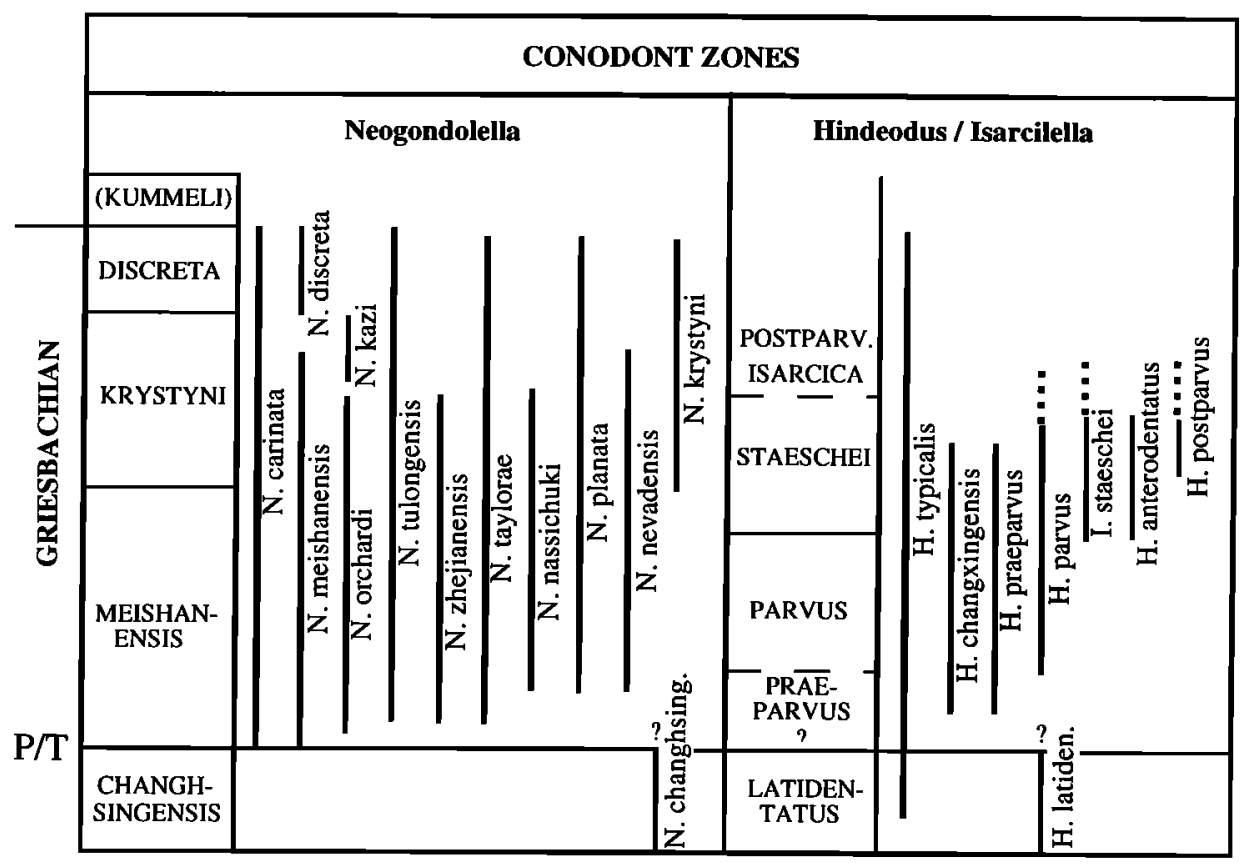

b)

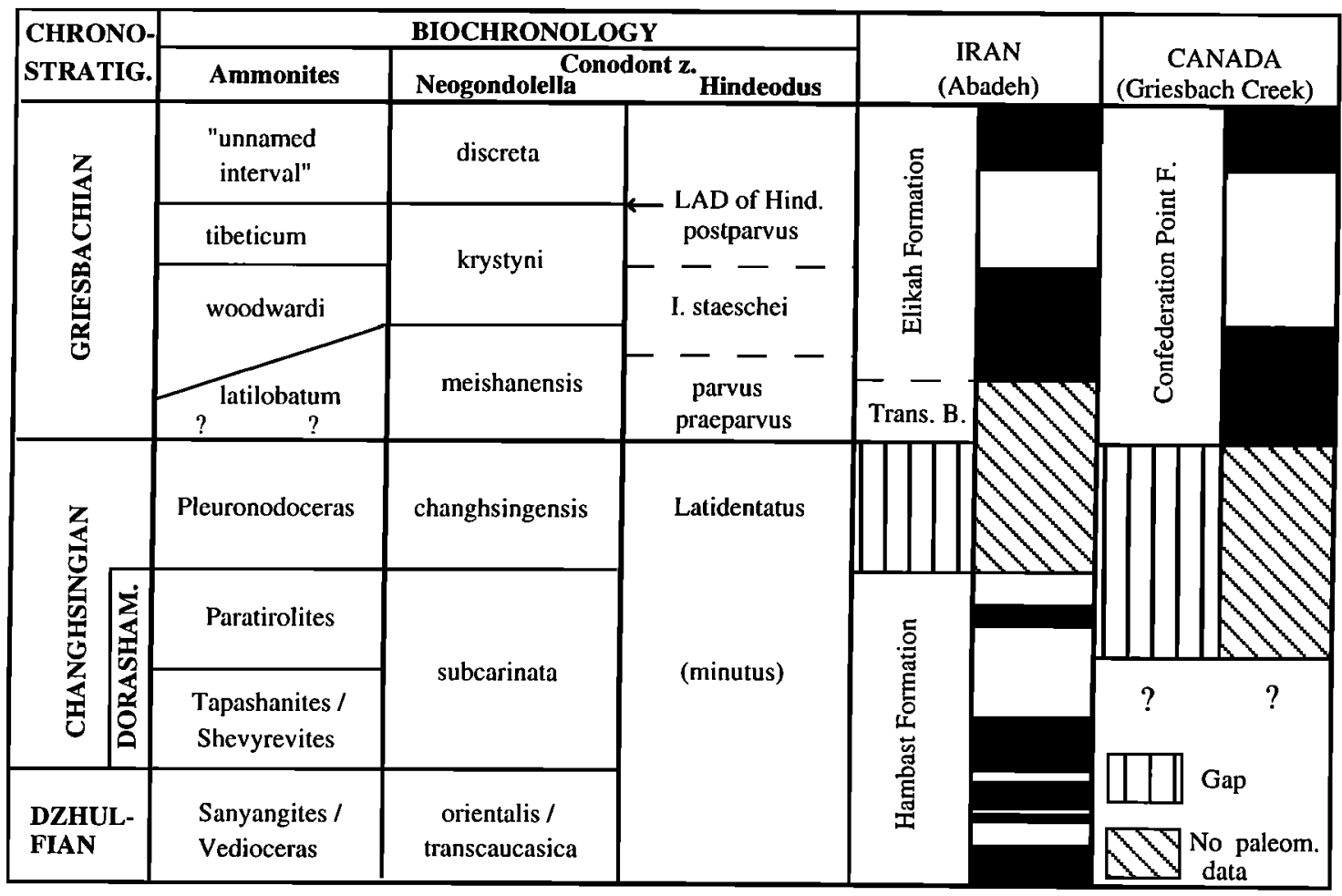

Figure 3. Upper Permian-Lower Triassic biochronology. (a) Lower Triassic conodont zonation considered in this study [Orchard and Krystyn, 1998]. (b) Integrated conodont and ammonoid zonations considered for the Upper Permian [Kozur, 1990, 1995] and the Lower Triassic [Orchard and Krystyn, 1998]. The Lower Triassic magnetostratigraphic sequences obtained from Abadeh (this study) and from the Griesbach Creek section (northern Canada [Ogg and Steiner, 1991]) are also shown. 
correlate with the Discreta zone of Orchard and Krystyn [1998], and it should be represented in Abadeh from 11 to $17.5 \mathrm{~m}$, above the last Hindeodus and below the first record of the Dienerian ammonoid genus Proptychites at $18 \mathrm{~m}$. From the same horizon, IJRG [1981] also mention the presence of the conodont $N$. dieneri, a record that we unfortunately could not confirm.

\section{Paleomagnetic Results}

Approximately 90 paleomagnetic samples were drilled within unit 7 of the Hambast Formation and 40 samples in the base of the Elikah Formation. Paleomagnetic measurements were carried out with a CTF three-axis SQUID magnetometer in the magnetically shielded room at the Institut de Physique du Globe de Paris. Samples were thermally demagnetized in $\sim 20$ steps using a laboratory-built furnace. The paleomagnetic directions were determined by leastsquares analysis, and the statistical method of Fisher [1953] was used to compute the mean directions.

Examples of thermal demagnetization diagrams for samples from the Hambast Formation (Figures 4a-4d) and from the Elikah Formation (Figures $4 \mathrm{e}-4 \mathrm{f}$ ) are shown in Figure 4 after bedding correction. A low unblocking temperature component is first removed below $-250^{\circ} \mathrm{C}$. In the intermediate temperature range, between $250^{\circ} \mathrm{C}$ and $\sim 450^{\circ} \mathrm{C}$, a component is obvious in many samples, but its direction of reversed polarity before bedding correction cannot be precisely determined because of wide overlap of its temperature spectrum (Figures $4 \mathrm{a}$ and $4 \mathrm{c}$ ). These two latter examples show that the overlap is highly variable depending on the samples. Note that a similar situation was observed in Triassic limestones from Albania, Turkey, and Austria [Muttoni et al, 1996; Gallet et al, 1992, 1998]. In contrast, a high unblocking temperature component is clearly isolated between $450^{\circ} \mathrm{C}$ and $600^{\circ} \mathrm{C}$. This component, which has a shallow inclination after bedding correction, contains both polarities (see Figures $4 \mathrm{a}, 4 \mathrm{~b}, 4 \mathrm{c}, 4 \mathrm{e}$ and Figures $4 \mathrm{~d}, 4 \mathrm{f}$ respectively).

The unblocking temperatures suggest that the magnetization is carried by a mineral of the magnetite family. This is confirmed by alternating field (AF) demagnetization which removes most of the magnetization by $\sim 100 \mathrm{mT}$ (Figure $4 \mathrm{~b}$ ) and by isothermal remanent magnetization (IRM) experiments (Figure 5). Comparison between thermal and AF demagnetizations of specimens from the same core is interesting because different behaviours are observed. That difference essentially concerns the intermediate component which is totally overlapped when AF demagnetized. We remark that the component apparently isolated between about $20 \mathrm{mT}$ and $100 \mathrm{mT}$ is likely a combination of the intermediate- and high-temperature components removed in roughly the same proportion between the successive demagnetization steps. Although not obvious from the demagnetization behavior, hematite is also present in the analyzed samples. This latter mineral is indicated by IRM experiments, which show that the magnetization is not completely saturated by a $0.4 \mathrm{~T}$ field (Figure 5), together with measurements of low field magnetic susceptibility versus temperature dependencies (up to $700^{\circ} \mathrm{C}$ ). This magnetic mineralogy is similar to the one observed in Triassic samples of Hallstatt facies previously studied in Turkey and Austria [e.g., Gallet et al, 1992, 1998].

The component observed in the low temperatures has clearly the direction of the present day field before bedding correction (Figure $6 \mathrm{a}$ and Table 1). The directions isolated for the high- temperature component are shown in Figure 6b. Two groups of directions are observed, which yield a positive reversal test (Figure $6 \mathrm{c}$ and Table $1 ; \gamma=3.9^{\circ}$ for $\gamma_{\mathrm{c}}=5.9^{\circ}$ [McFadden and McElhinny, 1990]). The mean normal and reversed directions are tightly clustered with small $\alpha_{95}$ and are statistically distinct from the mean direction of the low unblocking temperature component (Figure $6 \mathrm{c}$ and Table 1). Note that the mean directions computed separately for the Upper Permian and the Lower Triassic are undistinguishable. The high unblocking temperature component determines a sequence of 14 magnetic intervals from the Upper Permian to the Lower Triassic (Figure 2). Some of them are stratigraphically very thin $(\sim 20 \mathrm{~cm})$, but each interval is defined by at least three samples. All these characteristics indicate that the high-temperature component isolated from the Abadeh section was acquired during the sediment deposition. Another strong argument for the primary origin of the magnetization comes from the magnetostratigraphic correlation which is obtained for the unit 7 of the Hambast Formation between the Abadeh and the Shahreza sections, although the sampling density of the latest section is about half that of the Abadeh section (Figure 7 [Besse et al, 1998]).

\section{Discussion}

A major question concerns the hemisphere of deposition of the Upper Permian to Lower Triassic sediments from the Abadeh section and thus the interpretation of the paleomagnetic data in terms of normal and reversed magnetic polarity. The mean direction estimated from Abadeh yields a paleolatitude of $7.7^{\circ}\left[6.2^{\circ}-9.3^{\circ}\right]$ (Table 1 ), which can be either south or north. A Southern Hemisphere origin would indicate a large clockwise rotation (of $\sim 130^{\circ}$ ) of the Abadeh section since the Lower Triassic, whereas a northern origin would indicate only a smaller rotation of $\sim 50^{\circ}$ in the opposite sense. The choice between these two possibilities depends on the comparison between the Abadeh reversal sequence and other magnetostratigraphic results obtained from marine sections for which the hemisphere of deposition is known. Such a comparison is shown in Figure 7, with data from Armenia [Kotlyar et al, 1984; Zakharov and Sokarev, 1991], Canadian Arctic [Ogg and Steiner, 1991], south China [Heller et al., 1988, 1995; Steiner et ah, 1989], and Pakistan [Haag and Heller, 1991]. In particular, there is no hemispheric ambiguity for results obtained from the Canadian Arctic sections [Ogg and Steiner, 1991]. We remark that the available data are scattered, as already discussed by Heller et al. [1995] (see the results from south China, Figure 7). However, there is a general agreement (except for one Chinese section, Figure 7) for considering that the lowermost Triassic (Lower to Upper Griesbachian) is of normal magnetic polarity. The same magnetic polarity is obtained in Abadeh only if the region was located in the southern hemisphere during the Upper Permian and the Lowermost Triassic. This solution, discussed by Besse et al. [1998] in the realm of the Tethyan area, will be therefore considered in the following discussion.

The magnetostratigraphy of the Upper Permian from Abadeh reveals a sequence of 10 magnetic intervals. The Upper Dzhulfian is characterized by a predominant normal magnetic polarity with the occurrence of three short reversed intervals, while the Dorashamian has a predominant reversed magnetic polarity with only one short normal interval (Figure 2). The location of the Permo-Triassic boundary exactly corresponds to a change in magnetic polarity (from a reversed polarity to a 
a) IR2911A

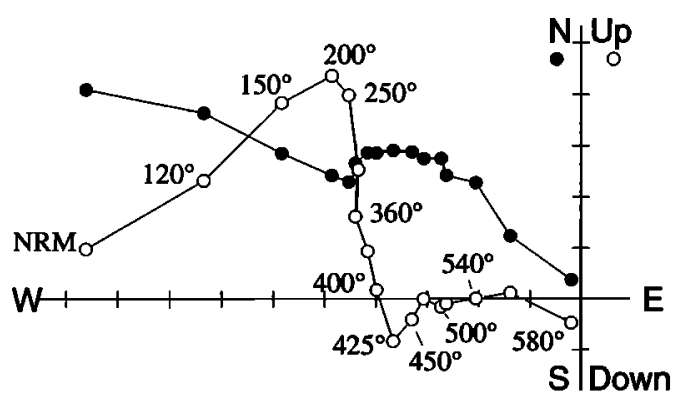

Scale: $1 \mathrm{e}-4 \mathrm{~A} / \mathrm{m}$

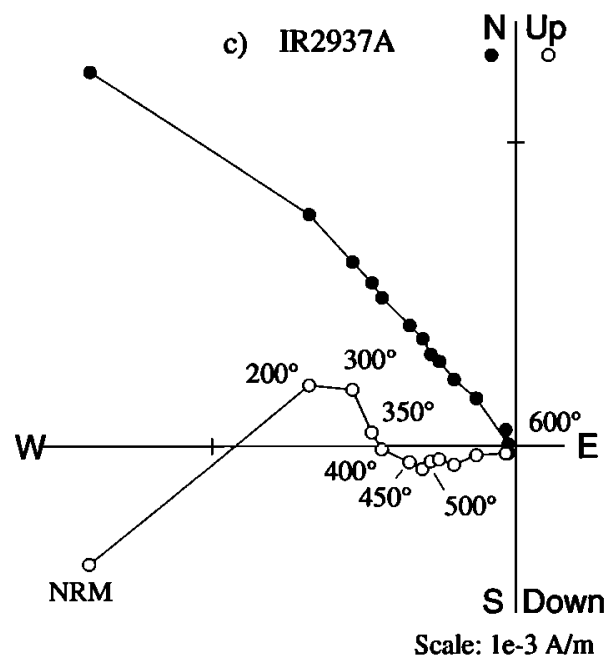

e) IR3114A

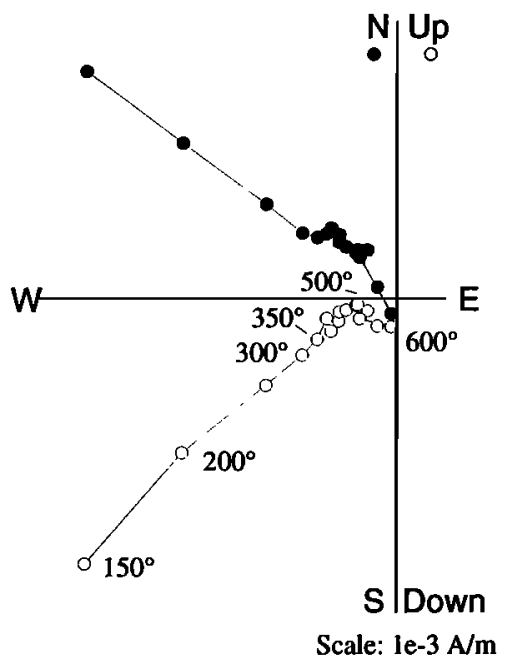

b) IR2911B

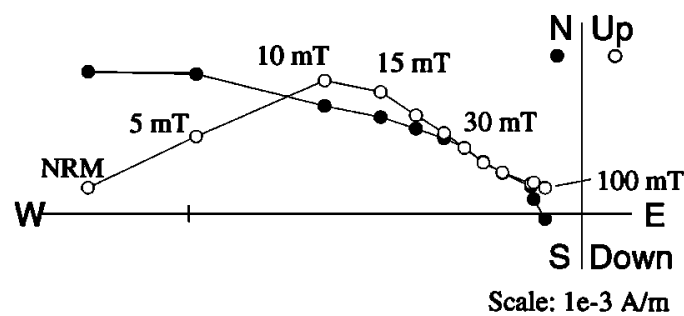

d) IR2932A

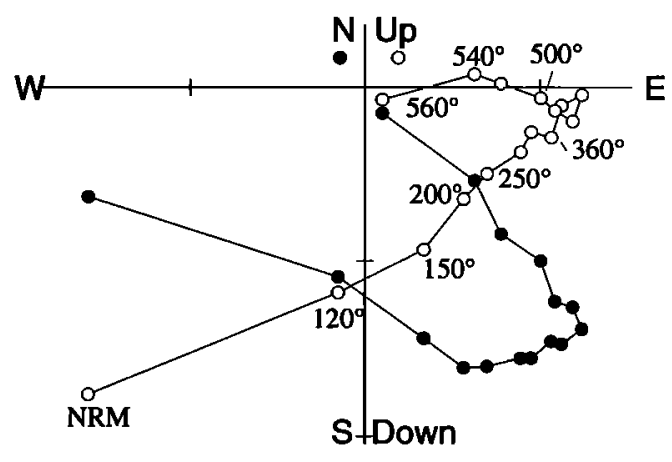

Scale: $1 \mathrm{e}-4 \mathrm{~A} / \mathrm{m}$

f) IR3105A

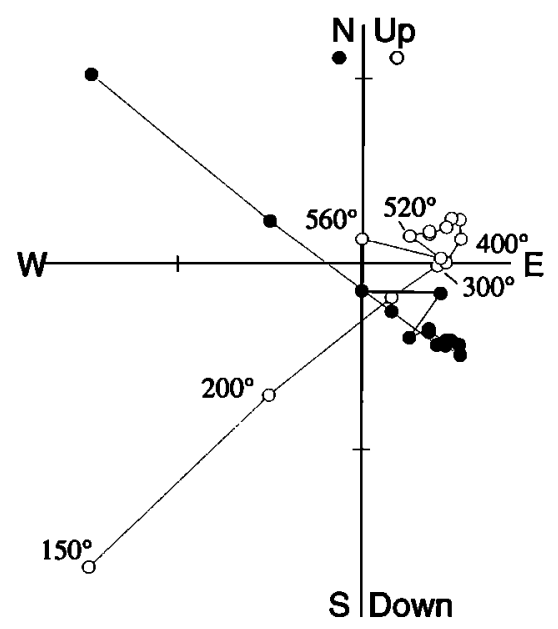

Scale: le-4 A/m

Figure 4. Examples of thermal and alternating field demagnetization of samples from the Abadeh section. Solid (open) symbols are in the horizontal (vertical) plane. All diagrams are in stratigraphic coordinates. (a-d) samples from the Permian Hambast Formation, (e-f) samples from the Triassic Elikah formation. 


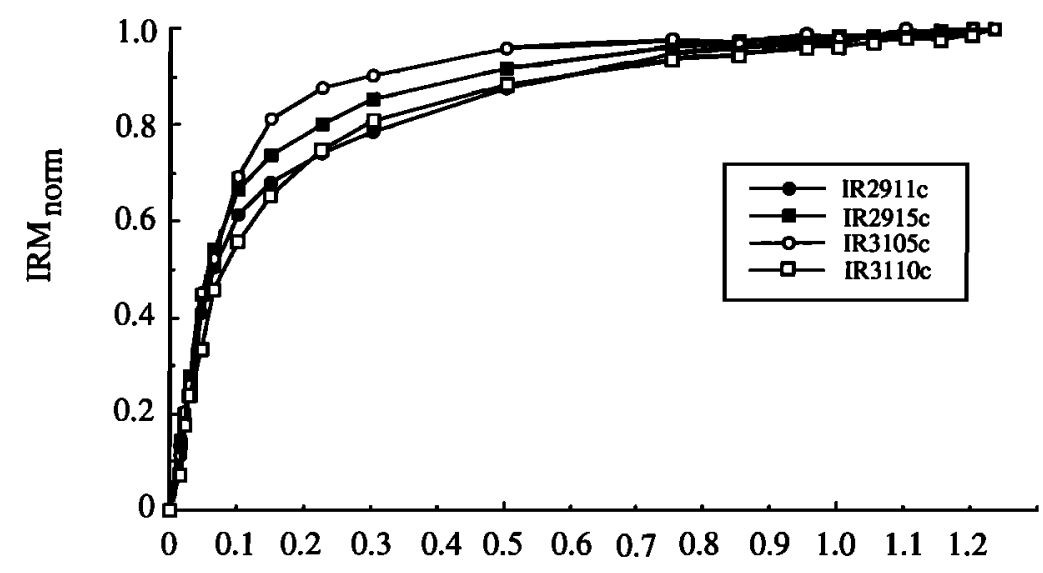

Applied field (Tesla)

Figure 5. IRM analyses of two samples from the Hambast Formation (solid symbols) and two samples from the Elikah Formation (open symbols).

normal one). A normal polarity interval is observed during the lower half of the Griesbachian from Abadeh. The Griesbachian/Dienerian boundary occurs within another normal polarity interval.

The Lower Triassic magnetic polarity sequence from Abadeh is concordant with the one obtained from the well-dated Griesbach Creek section from Canada (Figures $3 \mathrm{~b}$ and $7 \mathrm{O} \mathrm{gg}$ and Steiner, 1991]). In particular, they show the presence of a normal interval during the uppermost part of the Griesbachian and the Griesbachian/Dienerian boundary, which is not found in the Chinese sections [Steiner et al, 1989, 1993]. Ogg and Steiner [1991] proposed the occurrence of an additional short normal polarity interval during the Upper Griesbachian (called GN2) that we do not observe in Abadeh. This event is based on the stratigraphic correlation between the poorly dated Creek of Embry and the Griesbach Creek sections. Note that Hounslow et al. [1996] also suggested the occurrence of other very short polarity intervals during the Griesbachian from Central Svalbard (Barents Sea region) sections, which remain unconfirmed and not well described since no paleomagnetic analysis is provided.

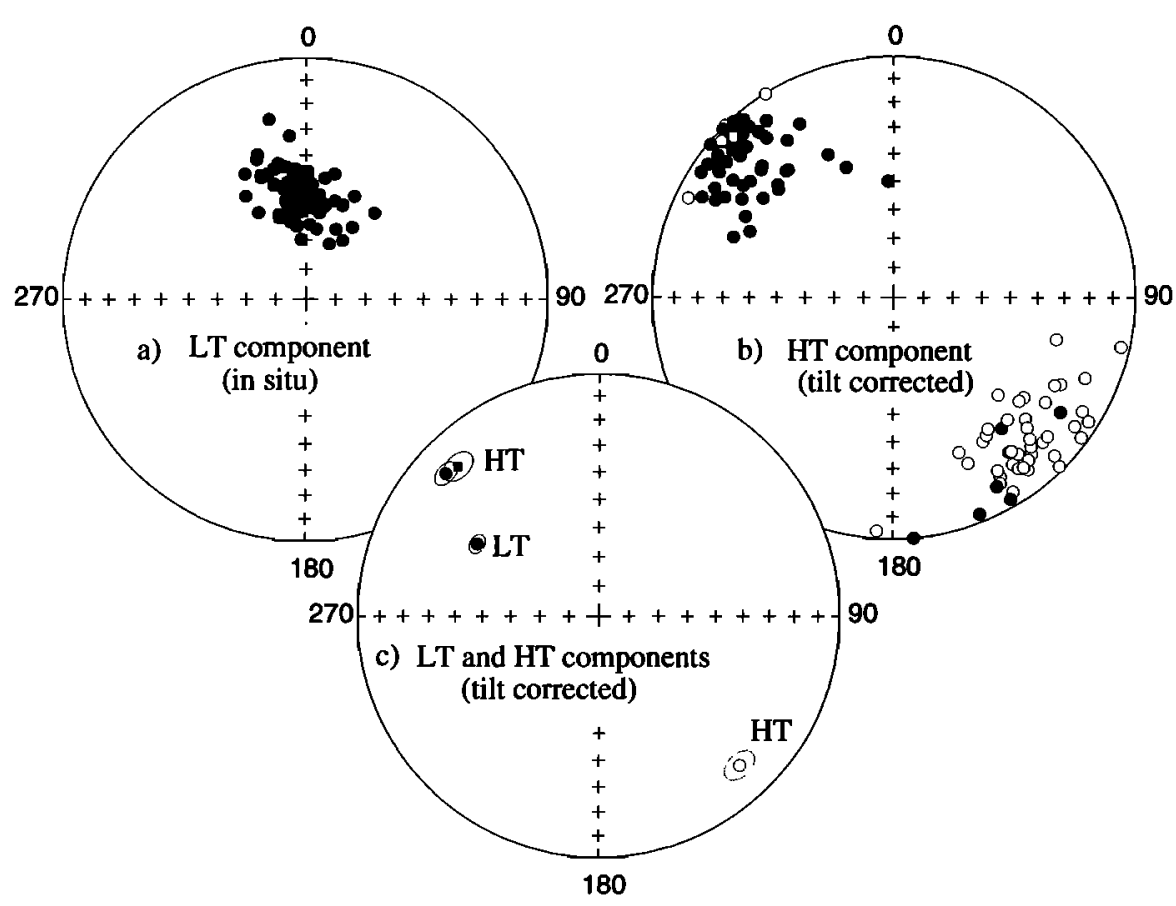

Figure 6. Directions of the (a) low (LT) and (b) high (HT) unblocking temperature components isolated through the Abadeh section by thermal demagnetization. The solid (open) symbols indicate directions of positive (negative) inclinations. The directions of the LT component are shown before tilt correction, whereas the other directions are presented after tilt-correction. (c) Tilt-corrected mean directions of both components. The solid square corresponds to the inverted mean direction of the HT component having a negative inclination. 
Table 1. Mean Directions Estimated for the Remagnetization and Characteristic Components From the Abadeh Section

\begin{tabular}{|c|c|c|c|c|c|c|c|}
\hline \multirow[b]{2}{*}{ Component } & \multirow[b]{2}{*}{$N$} & \multicolumn{2}{|c|}{$\begin{array}{l}\text { Before Tilt } \\
\text { Correction }\end{array}$} & \multicolumn{2}{|c|}{$\begin{array}{l}\text { After Tilt } \\
\text { Correction }\end{array}$} & \multirow{2}{*}{$\begin{array}{l}\alpha_{94}, \\
\text { deg }\end{array}$} & \multirow[b]{2}{*}{$K$} \\
\hline & & $D, \operatorname{deg}$ & $I, \mathrm{deg}$ & $D$, deg & $I, \mathrm{deg}$ & & \\
\hline $\begin{array}{l}\text { LT component } \\
\text { HT component }\end{array}$ & 93 & 356.2 & 53.6 & 299.8 & 41.3 & 25 & 34.4 \\
\hline Normal & 47 & 156.9 & -28.6 & 136.5 & -15.8 & 4.8 & 19.6 \\
\hline Reversed & 54 & 332.0 & 30.0 & 312.8 & 14.3 & 3.7 & 29.2 \\
\hline General & 101 & 154.4 & -29.5 & 134.5 & -15.2 & 29 & 23.7 \\
\hline
\end{tabular}

$N$ is number of samples; $D$, is declination; $I$, is inclination ; LT, low temperature; HT, high temperature.

The comparison between the different magnetostratigraphic results available for the Upper Permian is more difficult (Figure 7). A problem concerns the magnetostratigraphic sequence obtained from the Dorasham section [Kotlyar et al, 1984; Zakharov and Sokarev, 1991]. Indeed, no correlation is possible with the Abadeh section, despite the fact that the same formation was investigated. We regret that the paleomagnetic analysis carried out on samples from the Dorasham section has never been described, the related results being only shown as a black-white sequence by Kotlyar et al. [1984] and Zakharov and Sokarev [1991]. We have therefore no explanation for the discrepancies between the Abadeh and the Dorasham sections. Major problem in the determination of the characteristic magnetic components in samples from the Armenian section cannot be excluded and additional information on this section thus clearly is required.

The comparison between the Abadeh and the Nammal Gorge magnetostratigraphic sequences is fortunately easier (Figure 7). The detailed biostratigraphic reinvestigations of Wardlaw and Pogue [1995] from the Pakistani section yield a quite new and different age calibration for this latter section. They indicate that the upper part of the Chhidru Formation has a Dorashamian age and no longer a Dzhulfian age as this was previously considered by IJRG [1981] and others [e.g., Shen et al, 1984; Sweet, 1992]. Following this new constraint, a very satisfactory correlation is obtained between the Abadeh and the Nammal Gorge sections for the Upper Dzhulfian and the Lower Changhsingian (Dorashamian). The same magnetic polarity pattern is indeed observed, although two of the three very short magnetic polarity intervals found in Abadeh during the Upper Dzhulfian appear to be missing in Nammal Gorge. This difference is likely due to an insufficient number of samples collected in this part of the Nammal Gorge section.

Concerning the Chinese sections, there is a complete lack of internal correlation between the Linshui and Wulong/Shuijang sections, although the same formation was sampled [Heller et $a l, 1995]$. The two sequences appear roughly opposite in terms of magnetic polarity (Figure 7). Moreover, the magnetostratigraphic data independently obtained in Shangsi from the same section by Steiner et al. [1989] and Heller et al. [1988] are surprisingly different. Heller et al. [1995] attribute these differences to sampling gaps and magnetization instabilities in the Shangsi section (so-called "GPW") studied by Steiner et al. [1989]. Both cases clearly pose the problem of the reliability of the paleomagnetic data obtained from these sections where a complex paleomagnetic behaviour is often observed. Another explanation could be the occurrence of rapid changes in sedimentation conditions between the different Chinese sections, that neither the biostratigraphic nor the stratigraphic data would be able to detect.

Upper Permian magnetostratigraphic results were also obtained from the Chinese Meishan section (Figure 7[Yin et al., 1996b]). Yin et al. [1996a] have recently proposed to determine the base of the Triassic in a new Global Stratotype Section and Point (GSSP) at Mejshan by the FAD of the conodont Hindeodus parvus. (the choice for a stratotype is indeed presently under discussion [see Baud, 1996]). A new analysis by Orchard and Krystyn [1998] shows that the neogondolellid conodonts of the underlying so-called Transitional beds 25 and 26 from this section have strictly Triassic character and are not known from the Permian strata lying below. Moreover, these conodonts are also present in the Otoceras concavum and/or $O$. boreale ammonoid zones from Canada, which are widely considered as basal Triassic faunal intervals. The paleomagnetic data from the Meishan section still have not been described in detail. This is a very serious problem in an area where strong remagnetization clearly occurred [e.g., Dobson et al, 1993]. However, in contrast with the Dorasham section from Armenia, the Meishan magnetic sequence show a similar pattern to the one of the Wulong/Shuijiang and GPW Shangsi sections (Figure 7) [Steiner et ah, 1989; Heller et al, 1995]. The Lower Changhsingian seems characterized by the occurrence of a normal polarity interval at its base, then followed by one (Wulong/Shuijiang and GPW Shangsi) or several short normal polarity intervals (Meishan). At least one normal polarity interval is observed during the Upper Changhsingian. Doubt exists regarding the polarity state of the magnetic field during the uppermost Permian. In Meishan, and perhaps in Wulong/Shuijiang, the Permian-Triassic boundary occurs during a normal magnetic polarity. The comparison between this broad sequence and the data obtained from Abadeh and Nammal Gorge can be made only for the Lower Changhsingian: the same magnetic polarity sequence is observed between the Abadeh, Nammal Gorge, Wulong/Shuijiang, and the GPW Shangsi sections. Two additional short normal polarity intervals are present in Meishan, which are not observed in Abadeh probably because the Iranian section has a more reduced sedimentation rate. A similar predominance of normal magnetic polarity also is observed during the Upper Dzhulfian from Abadeh and during the time-equivalent interval from the Wulong/Shuijiang and GPW Shangsi sections. The Wulong/Shuijiang section seems to confirm the occurrence of at least two short reversed polarity intervals during this period.

\section{Conclusion}

Taking into account the similarity between the Abadeh, Shahreza, Nammal Gorge, Wulong/Shuijiang, GPW Shangsi, and Meishan sections, we have tentatively constructed a composite magnetic polarity timescale for the Upper Permian (Figure 7). We insist on the fact that this preliminary timescale is not complete since no magnetostratigraphic data are available for the Wordian (roughly equivalent to the Murgabian). The data from Nammal Gorge only indicate that the end of the Kiaman superchron is older than the Wordian/Capitanian boundary [Haag and Heller, 1991; Wardlaw and Pogue, 1995]. This stage boundary was recently dated by Bowring et al [1998] at around $265 \mathrm{Ma}$, which thus provides the youngest age estimate possible for the end of the Kiaman 


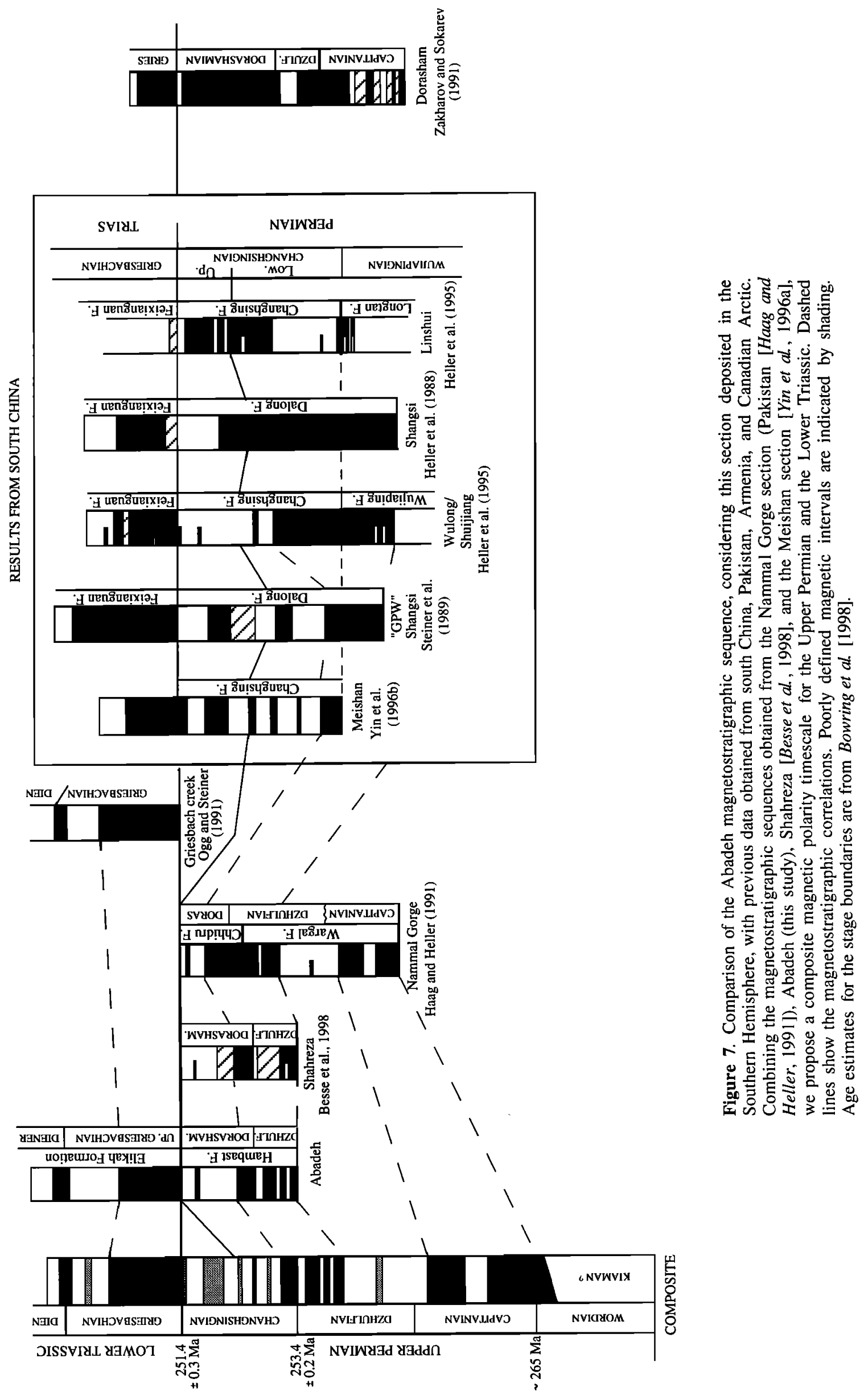


superchron [see also Opdyke, 1995]. The uppermost Permian (Upper Changhsingian) GPTS is uncertain (shaded in Figure 7) and must be confirmed, in particular, by providing additional data (or information) on the magnetostratigraphy from the Meishan section. If confirmed, these results together with those from Abadeh and Nammal Gorge would indicate a relatively high magnetic reversal frequency during the uppermost part of the Permian (Upper Dzhulfian-Changhsingian) with more than 15 magnetic reversals during a few million years. New $U / P b$ zircon geochronologic data from South China show that the Changhsingian stage could have a duration $<3$ Myr (Changhsingian/Dzhulfian boundary dated at $253.4 \pm 0.2 \mathrm{Ma}$ by Bowring et al. [1998]). In contrast, the reversal frequency was much lower during the Capitanian and the older part of the Dzhulfian, in agreement with the idea that the reversal process progressively resumed after the Kiaman superchron.

Acknowledgments. We thank Ahmad Zadeh and the Geological Survey of Iran, which made this study possible. We are also grateful to A. Baud for very helpful comments on the manuscript and F. Golshani for his help during the field work. L. Krystyn thanks the Austrian National Committee for funding his tieldwork within IGCP project 359. K. Kozur generously assisted in the determination of the conodont fauna. This is the IPGP contribution 1629 and INSU « Intérieur de la Terre» 196.

\section{References}

Baud, A., The Permian-Triassic boundary: Recent developments, discussion and proposals, Albertiana, 18, 6-9, 1996.

Baud, A., V. Atudorei, and Z Sharp, Late Permian and Early Triassic evolution of the northern Indian margin: Carbon isotope and sequence stratigraphy, Geodyn. Acta, 9, 57-77, 1996.

Besse, J., F. Torca, Y. Gallet, L. Ricou, L. Krystyn, and A. Sandi, Late Permian to late Triassic paleomagnetic data from Iran: Constraints on the Iranian block through the Tethys ocean, Geophys J. Int, 135 , 77-92, 1998.

Bowring, S., D. Erwin, Y. Jin, M. Martin, K. Davidek, and W. Wang. $\mathrm{U} / \mathrm{Pb}$ Zircon geochronology and tempo of the end-Perman mass extinction, Science, 280, 1039-1045, 1998.

Dobson, J.P., F. Heller, Z.-L. Li, and H. Mauritsch, Paleomagnetic and rock magnetic investigations of the Changxing Permian-Triassic section, Zhejiang province, China, Geophys Res. Lett., 20, 1667$1670,1993$.

Embleton, B., M. McElhinny, X. Ma, Z. Zhang, and Z. Xiang Li, PermoTriassic magnetostratigraphy in China The type section near Taiyuan, Shanxi Province, north China, Geophys. J Int., I26, 382388,1996

Erwin, D., The Permo-Trassic extinction, Nature, 367, 231-236, 1994

Fisher, R.A., Dispersion on a sphere, Proc R. Soc London, Ser. A\#217, 295-305, 1953.

Gallet, Y., J. Besse, L Krystyn. J Marcoux, and H Théveniaut, Magnetostratigraphy of the Late Triassic Bolucektasi Tepe section (southwestern Turkey): Implications for changes in magnetıc reversal frequency, Phys. Earth Planel. Inter. 73, 85-108, 1992

Gallet, Y, L. Krystyn, and J. Besse, Upper Anisian to Lower Carnian magnetostratigraphy from the northern Calcareous Alps, J Geophys. Res., 103, 605-622, 1998.

Gialanella, P., F. Heller, M Haag, D. Nurgalıev, A. Borisov, B. Burov, P. Jasonov, D Khasanov, S. Ibragimov, and I. Zharkov, Late Permian magnetostratigraphy of the eastern Russian platform, Geol. Munbouw, 76, 145-154, 1997.

Golshani, F., H. Partoazar, and K. Seyed-Emami, Permian-Triassic boundary in Iran, Mem. Soc. Geol. It, 34, 257-262, 1986.

Haag, M., and F. Heller, Late Permian to Early Triassic magnetostratigraphy, Earth Planet Sci. Lett, 107, 42-54, 1991.

Heller, F., W. Lowrie, $\mathrm{H} \mathrm{Li}$, and J. Wang., Magnetostratigraphy of the Permo-Triassic boundary section at Shangsi, Earth Planet Sci. Lett., 88, 348-356, 1988.

Heller, F., C. Haihong, J. Dobson, and M. Haag, Permian-Triassic magnetostratigraphy- New results from south China, Phys. Earth Planet. Inter., 89, 281-295, 1995.
Hounslow, M., A. Mork, C. Peters, and W. Weitchat, Boreal Lower Triassic magnetostratigraphy from Deltadalen, central Svalbard, Albertiana, 17, 3-9, 1996.

Iranian-Japanese Research Group (IJRG), The Permian and the lower Triassic systems in Abadeh region, central Iran, Mem. Fac. Sci. Kyoro Univ., Ser. Geol. Mineral., 67, 134 pp., 1981.

Kotlyar, G., R. Kommissarova, A. Khramov, and I. Chediya, Paleomagnetism of upper Permian rocks from Transcaucasia (in Russian), Dokl. Akad. Nauk SSSR, 276, 669-674, 1984.

Kozur, H., Beiträge zur Conodontenfauna des Perm, Geol. Paläontol. Mitt. Innsbruck, 5/4, 1-44, 1975.

Kozur, H., The Permian-Triassic boundary in marine and continental sediments, Zentralbl. Geol. Paläontol, Tetl I, 11/12, 1245-1277, 1989.

Kozur, H., Significance of events in conodont evolution for the Permian and Triassic stratigraphy, Cour. Forschungsinst. Senckenberg., 117, 385-408, 1990.

Kozur, H., Permian conodont zonation and its importance for the Permian stratigraphic standard scale, Geol. Paläontol. Mitt. Innsbruck, 20, 165-205, 1995.

Kozur, H., H. Mostler, and A. Rahimi-Yazd, Beiträge zur Mikropaläontologie permotriadischer Schichtfolgen, teil II, Neue Conodonten aus dem Oberperm und der basalen Trias von Nord- und Zentraliran, Geol. Paläontol. Mitt Innsbruck, 5/3, 1-23, 1975.

McFadden, P., and M. McElhinny, Classification of reversal test in paleomagnetism, Geophys. J. Int., 103, 725-729, 1990.

Mei, S, Y. Jin, and B. Wardlaw, Succession of Wuchiapingian conodonts from north-eastern Sichuan and its worldwide correlation, Acta Micropaleontol. Sin., 11, 121-139, 1994.

Muttoni, G., D. Kent, S. Meço, A. Nicora, M Gaetant, M. Balini, D. Germani, and R Rettori, Magneto-biostratigraphy of the Spathian to Anisian (Lower to Middle Triassic) Kçira section, Albania, Geophys. J. Int., I27, 503-514, 1996.

Ogg, J., and M. Steiner, Early Triassic magnetıc polarity time scale: Integration of magnetostratigraphy, ammonite zonation and sequence stratigraphy from statotype sections (Canadian Arctic Archipelago), Earth Planet. Sci Letl., 107, 69-89, 1991.

Opdyke, N, Permo-Carboniferous magnetostratigraphy. In Geochronology, Time Scales and Global Strattyraphic Correlation, edited by W. Berggren et al., Spec. Publ. SEPM Soc. Sediment. Geol., 54, 3I-50, 1995.

Orchard, M., and L. Krystyn, Conodonts and zonation of the lowermost Triassic of Spiti, and correlation of the Permian-Triassic boundary, Riv. Ital. Paleontol., 104, 341-368, 1998.

Ruzhencev, V, and T. Sarycheva, Razvitie i smena morskich organizmov na rubezhe paleozoja i mesozoja, Tr. Paleontol. Inst. Akad. Nauk SSSR, 108, 431 pp., 1965.

Sepkoskı, J., The taxonomic structure of periodic extinction, in Global Catastrophies in Earth History: An Interdisciplınary Conference on Impacts, Volcanism and Mass Mortality, edited by VL Sharpton and P.D. Ward, Spec. Pap) Geol. Sor. Am, 247, 33-44, 1990.

Shen, J.-Z., C. Chen, Y. Wang, L. Rut, Z. Liao, Y Bando, K. Ishi1, K. Nakazawa, and $K$. Nakamura, Permıan-Triassıc boundary in middle and eastern Tethys, J. Foc. So. Hokkardo Unuv, Ser. IV, 2 (1), 133181, 1984.

Steıner, M., J. Ogg, Z. Zhang, and S. Sun, The late Permian/Early Triassic magnetic polarity time scale and plate motions of south China, J. Geophys. Res., 94, 7343-7363, 1989.

Steıner, M., M. Morales, and E Shoemaker, Early Triassic magnetostratigraphic correlation, Spec. Publ. Soc Econ. Paleontol. Mineral. , 49, 41-57, 1993

Sweet, W, Uppermost Permian and Lower Triassic conodonts of the Salt Range and Trans-Indus Ranges, West Pakistan, in Stratigraphic Boundary Problems, Permian and Triassic of West Pakıstan, edited by B. Kummel and C. Teicherl, Spec. Publ. 4, pp. 207-275, Dep. Of Geol., Univ. Of Kansas, Lawrence, KS, 1970.

Sweet, W., A conodont-based high-resolutıon bıostratigraphy for the Permo-Triassic boudary interval, in Perno-Triassic Events in the Eastern Tethys, edıted by W. Sweet et al., pp. 120-133, Cambridge Univ. Press, New-York, 1992.

Taraz, H., Permo-Triassic section in central Iran, Bull. Am. Assoc. Pet. Geol., 53, 688-693, 1969.

Taraz, H., Uppermost Permian and Permo-Triassic transition beds in Central Iran, Bull. Am. Assoc. Pet. Geol, 55, 1280-1294, 1971.

Taraz, H, Geology of the Surmaq-Deh Bid area, Abadeh region, central Iran, Rep. 37, 148 pp., Geol. Surv. Iran, 1974. 
Théveniaut, H, C. Klootwijk, C. Foster, and J. Giddings, Magnetostratigraphy of the late Perman coal measures of the Sydney and Gunnedah basins: A regional and global correlation tool, Paper presented at 28th Newcastle Symposium on Advances in the Study of the Sydney Basin, Dep of Geol, Univ. of Newcastle, Newcastle, N S W., Australia, 1994

Tozer, E., A standard for Triassic ttme, Bull. Geol Surv Can., 156, 103, 1967.

Tozer, E., Age and corelation of the Otoceras beds at the PermianTriassic boundary, Albertiana, 14, 31-37, 1994

Wang, C., Conodonts of Permian-Triassic boundary beds and biostratıraphic boundary, Acta Paleontol Sin. , 34, 129-151, 1995.

Wardlaw, P., and K. Pogue, The Perman of Pakistan, in The Perman of Northern Pangea, Sedimentary Basins and Economic Resources, vol 2, edited by $P$. Scholle et al., pp.215-224, Springer-Verlag, New York, 1995.

Yin, H., W. Sweet, B Glenıster, G Kollyar, H. Kozur, N. Newell, J Sheng, Z. Yang, and Y. Zakharov, Recommendation of the Meishan section as Global Stratotype Section and Point for basal boundary of Triassic system, Newsl. Stratigr., 34, 81-108, 1996 a.

Yin, H., W. Shunbao, D. Meıhua, Z. Kexin, T. Jinnan, Y Fengqing and
L. Xulong, The Meishan sectıon, candidate of the global stratotype section and point of Permian-Triassic boundary, in The PaleozoucMesozoic Boundary, edited by Yin H, pp. 31-48, China Univ of Geosci. Press, Wùhan, 1996 b.

Zakharov, Y., and A. Sokarev, Permian-Triassic paleomagnetism of Eurasia, in Proceedings of Shallow Tethys 3, Spec. Publ. 3, pp. 313323. Satto Ho-on Ka i, Sendai, 1991.

Zhao, J., X. Lrang, and Z. Zheng, Late Permian cephalopods of South China, Palceontol. Sin. Ser. B, I2 pp 194, 1978.

J. Besse. Y. Gallet, and L. E. Ricou, Laboralorie de Paléomagnétisme et Géodynamique, UMR CNRS 7577, IPG Paris, Tour 12-24. $1^{\text {a }}$ élage, 4 Place Jussieu, F-75252 Paris cedex 05 (gallet@ipgp.jussıu.fr)

L. Krystyn, Institute for Paleontology, Althanstrasse 14, A-1090 Vienna, Austria.

A. Saidi, Geological Survey of Iran, P.O. Box 13185, 1494 Tehran, Iran.

(Received September 23, 1998; revised June 1, 1999;

accepted June 9, 1999) 